Eugène Devéria 1805-1865: Paul Mironneau, Eugène Devéria, La peinture et l'histoire ; Guillaume Ambroise, Eugène Devéria, Variations sur les genres artistiques

\title{
Lise Sabourin
}

\section{(2) OpenEdition \\ Journals}

Édition électronique

URL : http://journals.openedition.org/studifrancesi/9293

DOI : 10.4000/studifrancesi.9293

ISSN : 2421-5856

Éditeur

Rosenberg \& Sellier

Édition imprimée

Date de publication : 1 juin 2008

Pagination : 212

ISSN : 0039-2944

\section{Référence électronique}

Lise Sabourin, «Eugène Devéria 1805-1865: Paul Mironneau, Eugène Devéria, La peinture et l'histoire : Guillaume Ambroise, Eugène Devéria, Variations sur les genres artistiques », Studi Francesi [En ligne], 154 (LII | I) | 2008, mis en ligne le 30 novembre 2015, consulté le 12 janvier 2021. URL : http://

journals.openedition.org/studifrancesi/9293; DOI : https://doi.org/10.4000/studifrancesi.9293

Ce document a été généré automatiquement le 12 janvier 2021.

\section{c)}

Studi Francesi è distribuita con Licenza Creative Commons Attribuzione - Non commerciale - Non opere derivate 4.0 Internazionale. 


\title{
Eugène Devéria 1805-1865: Paul Mironneau, Eugène Devéria, La peinture et l'histoire ; Guillaume Ambroise, Eugène Devéria, Variations sur les genres artistiques
}

\author{
Lise Sabourin
}

\section{RÉFÉRENCE}

Eugène Devéria 1805-1865: Paul MIRONNEAU, Eugène Devéria, La peinture et l'histoire, Musée national du château de Pau.

Guillaume AMBROISE, Eugène Devéria, Variations sur les genres artistiques, Musée des BeauxArts de Pau, Réunion des Musées nationaux, 2005, pp. 152, ill.

1 À l'occasion du bicentenaire de la naissance de Devéria, la ville de Pau a présenté deux expositions dont le catalogue commun, confié aux conservateurs respectifs des musées concernés, présente bien sûr la liste des œuvres montrées (pp. 133-143) et d'excellentes reproductions en couleurs de ses tableaux et dessins, ainsi que des articles de spécialistes qui ont l'intérêt pour nous d'entrecroiser les regards entre art et littérature.

Outre les relations de cet esprit calviniste avec la Grande-Bretagne (Stephen BANN, pp.65-88), c'est son rapport romantique à l'histoire qu'explorent Marie-Claude CHAUDONNERET (De la peinture d'histoire à l'illustration, le 'genre historique', pp. 103-108) et Paul MIRONNEAU (L'histoire au goût d'un romantique, pp. 109-132). Pour leur part, MarieHélène GIRARD (citant un vers du peintre, Un de ces nobles noms rayonnant d'espérance..., pp. 25-46), Barthélémy JOBERT (Une figure d'artiste au temps du romantisme, pp. 47-64) et Guillaume AMBROISE (Un portraitiste méconnu, pp.85-96) scrutent les liens entre le 
Cénacle et les artistes à travers la figure de Devéria et ses portraits de contemporains. Son Journal (1848-1864), exercice essentiellement spirituel à ses yeux, atteste aussi de sa vocation poétique (voir p. 150, la publication entreprise aux Éditions William Blake) et fait encore l'objet d'une analyse de sa «veine dramatique» (Claude MENGES-MIRONNEAU, pp. 97-102).

3 Cet esprit façonné par le romantisme de 1820-1830 ne peut donc qu'interroger notre connaissance littéraire par ses variations génériques, des portraits et des lithographies - pour illustrer Quentin Durward de Scott par exemple - aux scènes de genre et d'histoire qui firent sa célébrité auprès des littérateurs de son temps. 